\title{
The Effects of the Professional Development Program Supported by On-the-job Visits on the Pedagogies of Mathematics Teachers
}

\author{
Recai Akkuş ${ }^{1 *}$, Melisa Karakaya ${ }^{1,2}$ \\ ${ }^{7}$ Bolu Abant Izzet Baysal University, TURKEY \\ 2 Development Workshop Cooperative, TURKEY \\ *CORRESPONDENCE: $\square$ piagora@yahoo.com
}

\begin{abstract}
Researchers have approached to teacher change in different ways: as a learner, as a teacher, and as a colleague. This study aims to analyze teachers' pedagogical changes within the professionally collaborated training program supported with on-the-job visits in their teaching environments. Five elementary mathematics teachers were involved in the study which was organized as a longitudinal professional program aiming at teachers' classroom practices. By analyzing teaching practices and interviews through Reformed Teaching Observation Protocol (RTOP), the results show that teachers had various characteristics in terms of enacting their pedagogical goals. The study concludes that sample classroom implementations and pedagogical discussions have impact on teachers' beliefs about putting pedagogical goals into practice.
\end{abstract}

Keywords: in-service education, on-the-job support, teacher education

\section{INTRODUCTION}

The changing and developing world requires individuals to develop new learning strategies and skills according to the needs of the world. In order for young students to catch the ever-changing world's needs, they should possess a philosophy of life-long learning perspective. Teachers play the critical role in that learning process, which should be aligned with teacher training and support. That is, teachers are the ones who can apply such changes to help students adapt to new conditions in the changing world.

One of the ways for helping teachers change their pedagogical practices is to guide them to be aware of their own teaching process (Pennington, 1995). Research on teacher change shows that teachers pass through a series of change/adaptation process during implementing new pedagogical approaches in their classrooms. These changes include perceptions about students, aligning teaching according to students' learning, sharing the authority in the classroom and understanding of students' abilities to construct mathematical knowledge (Clarke \& Hollingsworth, 2002; Hand, Norton-Meier, Gunel, \& Akkus, 2016; Nelson, 1997).

Weissglass (1994) and Reid and Zack (2010) emphasize that teacher change is hard, slow and painful because teachers resist to change their habits of teaching practices. Therefore, it is important to see that teacher change is a cultural event and teachers' emotions, beliefs and values should be accounted to support them in their journeys (learning content, pedagogy, educational policies etc.; reflecting on own practices;

Note: This article is based on the Master Thesis of the second author prepared at the Bolu Abant Izzet Baysal University.

Article History: Received 16 March $2020 \bullet$ Revised 5 June $2020 \bullet$ Accepted 4 July 2020

(C) 2020 by the authors; licensee Modestum. Open Access terms of the Creative Commons Attribution 4.0 International License (http://creativecommons.org/licenses/by/4.0/) apply. The license permits unrestricted use, distribution, and reproduction in any medium, on the condition that users give exact credit to the original author(s) and the source, provide a link to the Creative Commons license, and indicate if they made any changes. 
emotional regulations; process of changing classroom practices in relation to students, school administration, parents and colleagues).

Clark and Peterson (1984), who proposed a model about teacher thoughts and actions, emphasize that teachers have visible and invisible processes which are mutually interrelated. According to this model, teacher thought process consists of teacher planning (before and after actions), interactional thoughts and decisions and teacher theories and beliefs, which are not observable directly. On the other hand, teacher actions and observable effects consist of teacher and students' behaviors in class, student achievement and the like. Sherin, Sherin and Madanes (2000) emphasize that the focus of teacher research should be on how and why teachers do what they do as well as on what they do in class. Llinares and Krainer (2006) warn that finding answers to these questions is a challenge because teachers' learning is complex and is somewhat influenced by personal, social, cultural and political contexts. The complex structure of teaching starts developing long before (e.g., educational activities before schooling) teachers begin teaching professionally and continues during learning teaching at universities and thereafter the life-long process of learning teaching embarks on in the first years of actual teaching practice which may reach at some level of efficiency and maturation. Verschaffel, Greer and Torbeys (2006) mention that teachers' pedagogical content knowledge develops through teaching practice and therefore teacher learning is always in progress.

There are many factors affecting teacher change (Llinares \& Krainer, 2006), some of which are curriculum, teachers' own mathematical, pedagogical and pedagogical content knowledge, and students' alternative thoughts. In addition, expectations of parents and school administration may hinder teacher change. Moreover, Hand et al. (2016) found that teachers' belief that "they have control over students' learning" was an obstacle in teacher change. From this perspective, factors affecting change can be separated into two: external factors (curriculum, resources, expectations etc.) (Akkus \& Hand, 2011; Alger, 2009) and internal factors (belief, competencies etc.) (Clark \& Peterson, 1984).

Furthermore, there are other factors that lead teachers to change, which are socio-cultural factors, students' thought provoking behaviors, awareness of students' mathematical thinking, perspectives about learning and teaching, beliefs, and practices. This pedagogical change progresses in a circular pattern if the teacher reflects on own pedagogy and needs innovation in his/her classroom. However, teachers sometimes need professional development (PD) programs that push them to realize the routine in their pedagogical practices. Nelson (1997) expresses that these changes include perceptions about students (e.g., students' abilities to build mathematical knowledge), learning, teaching (i.e., teaching should be aligned with learning), and sharing the authority with students.

\section{PROFESSIONAL DEVELOPMENT}

Research on teacher professional development shows that teacher learning process has a complex structure in which many factors mutually interact with each other (Jones, Lubinski, Swafford \& Thornton, 1994; Llinares \& Krainer, 2006; Weissglass, 1994). Therefore, teacher PD programs should be planned in the accordance with teachers, their colleagues, context in which they interact and content of the course (Cohen, Raudenbush, \& Ball, 2003; Cooney, 1994; Llinares \& Krainer, 2006). In this manner, teachers should also take active roles in their professional development processes. In fact, teachers put on both student and teacher hats in PD programs to reflect on their own learning process, students' learning and their classroom practices (Wilkie, 2019). Moreover, Wilkie, by attributing to Johnson (1996), states that learning of teachers as professional development should be the on-going process of the school environment.

Additionally, Superfine (2019) declares that there have been new approaches that support teachers in their working sites through collaborative models, such as Bryk et al.'s (2015) Network Improvement Communities, Coburn and Penuel's (2016) Research-Practice Partnership and Penuel et al.'s (2011) Design-based Implementation Research. The common feature of these models is that they place teacher learning at the center of professional development such that teachers and researchers collaborate around the problems relevant to teachers' own context and circumstances. That is, researchers work with teachers rather than conducting research on teachers.

Researchers who study professional development have approached teacher change in three distinct but somewhat interconnected ways: teacher as a learner, teacher as a teacher, and teacher as a colleague (Llinares \& Krainer, 2006). These approaches have different research perspectives and settings during PD programs. Teachers learn through a series of activities during PD programs and they interact with their colleagues and 
learn through each other's classroom practices. It is crucial that these PD programs provide non-threatening environment for teachers to shed light on teacher change.

Teachers' professional development and learning has a potential of transforming all educational areas and is a complex issue (Castle \& Aichele, 1994). Simon (1997) states that teacher education and teacher professional development need a new point of view that lead teachers to develop new understanding of teaching and learning rather than new teaching methods or materials. Ball and Forzani (2009) emphasize that teacher practices should be the focus of such a new perspective in spite of its difficulties. Therefore, teachers critically need to reflect on their own pedagogical practices for gaining an awareness of competencies of teaching profession and having a meaningful understanding of their practices.

Teacher classroom practices are shaped within the school context, which directly or indirectly supports or limits teaching (Jones, 1997). Consequently, the context where teaching and learning take place is restructured based on the conditions in which teacher interacts (Castle \& Aichele, 1994). On the other hand, although teachers are welcomed to provide opinions during curriculum development, they are still forced to implement the curriculum imposed from outside (Llinares \& Krainer, 2006). In addition, we can say that students' profiles and parents' expectations also shape teacher classroom practices. Thus, teacher learning and pedagogical improvement continue to evolve with these conditions.

As Even and Tirosh (2002) and Simon (1997) state, teacher's knowledge and perception of mathematics and student learning interact within classroom environment and this interaction is affected by many factors: teachers' knowledge of mathematics, their self-efficacy about knowing and doing mathematics, their knowledge of teaching, personal beliefs about learning and teaching, perception about the nature of knowledge, education system, and persons participating education (principal, parents, colleagues, etc.) From this perspective, the factors shaping teachers' classroom environment show similarities with the factors affecting their professional development and learning. Therefore, teachers' understanding that learning mathematics is part of classroom culture and related with socio-mathematical norms is crucial for designing a learning environment where students take responsibilities of their own learning and have the opportunity to create mathematical norms (Even \& Tirosh, 2002; Yackel \& Cobb, 1996; Yackel, Rasmussen, \& King, 2000). On the other hand, this awareness and understanding do not happen automatically. This kind of manner should be a working part of teacher education (pre- and in-service). In other words, teachers learn about teaching by doing teaching and involving in a professional learning community.

When giving support for teacher change, it is also crucial to implement new pedagogical approaches in a real learning environment where teachers have the opportunity to see how their students react to new teaching approaches (Clarke, 1994). Some research on in-service PD programs and teacher education focus on increasing teachers' awareness of their teaching practices to improve their teaching. However, for this awareness emerges, there are some elements that must come together and mature that, in return, force teachers to act or move. Even though there is no priority in these elements, it is crucial that teachers can critique their own pedagogy and feel a need to change (Castle \& Aichele, 1994). For example, teachers' willingness to try something new may trigger the process (Goos \& Geiger, 2010). Teachers may feel uncomfortable with their classroom culture and get into new quest (Reid \& Zach, 2010). Thus, teacher change continues in a cyclic way until the new knowledge (experience, method, technique, point of view, etc.) becomes the daily routine of the teacher (Pennington, 1995).

NCTM (2000) emphasizes that teachers should have a coherent understanding of mathematical concepts and the ability to integrate flexible teaching strategies. Researchers such as Mewborn (2003), Sowder, Philipp, Armstrong and Schapelle (1998), Swafford, Jones and Thornton (1997) and Schifter (1998) show that teachers' knowledge of mathematical concepts is the key to manage to help students construct deep mathematical understanding of the concepts they discuss. Moreover, Schifter (1998) states that teachers should learn mathematics in the way that they are expected to teach. Therefore, PD programs should take teachers' mathematical thinking at the center of learning process. Teachers' expectation from PD programs is to face the implementations and materials that push their classroom practices forward (Günel \& Tanrıverdi, 2014). Within this regard, the important part of providing professional development is to open areas where teachers reflect on their own classroom practices (Pennington, 1995) and have the opportunity to improve their teaching rather than to supply hard materials and new tricks (Simon, 1997). Similarly, as Chazan and Ball (1995) emphasize, during PD programs, teachers do not replace their old (current) teaching methods and techniques with the new ones; rather, they develop an awareness about how and when to use the old ones. 
Supovitz and Turner (2000) state that in-service training/education has an important role for implementing educational reforms and new approaches as well as improving quality of education. Moreover, Lesh (2002) emphasizes that teacher education has to be interactional. There are some examples in mathematics education where teachers and researchers collaborate during PD programs (e.g. researchers get into teaching position and teachers take researcher role in their classrooms) (Ball \& Forzani, 2010; Diezmann \& Watters, 2015; Knight et al., 2015; Sykes, Bird, \& Kennedy, 2010; Wallace, Cederberg, \& Allen, 1994; Walshaw \& Anthony, 2008; Wasserman, 2015).

\section{THE CONTEXT OF TURKEY}

There have been several reforms in the education system in Turkey for the last few decades. For example, compulsory schooling was increased from five years to eight years in 1997 that impacted, for example, the rate of girls' schooling. With the changes in 1997 and 2005, teachers were forced to shift their philosophy of teaching towards more student-centered ways. However, as Babadoğan and Olkun (2006) stated, teachers did not get necessary support in the transition of the reforms. On the other hand, without having seen the results of the changes done in 1997 and 2005, the eight-year compulsory schooling system was replaced with the 4+4+4 model in 2012 (Ministry of National Education-MoNE, 2012a). This time, teachers were forced to adapt technological innovations in their classrooms. Thus, the support by the Ministry of National Education (MoNE) was no further than technological use (e.g., smartboard and tablet use).

In-service education in Turkey is generally organized by the MoNE for short term periods. Gunel and Tanriverdi (2014), by analyzing the history of in-service training that had been offered by the MoNE since the foundation of the Republic of Turkey in 1923, reported that in-service education had become more centralized and that the content of the seminars had focused on the adaptation of new programs instead of helping teachers to overcome the problems they faced. These programs mostly focused on certain skills in certain subjects rather than following up each other (Bağcı \& Şimşek, 2000). When we examine the systems in the countries that are at the top of international exams, we see that the teachers in these countries regularly participate in-service education programs according to their pedagogical needs (Eraslan, 2009). However, research conducted in Turkey showed that the majority of primary teachers participated technology related programs. Also, these teachers stated that they wanted to learn about the new education programs, new methods and techniques. The MoNE regularly surveys teachers' needs for in-service education. Technology and material related educational programs are mostly preferred by the teachers in Turkey (MoNE, 2012b). On the other hand, Baştürk (2012) found that the teachers were not satisfied with the programs offered by the MoNE. The teachers declared that they were not able to apply what they had learned during the programs in their classrooms. Moreover, Gokmenoğlu, Clark and Kiraz (2016) found that the in-service education programs offered by the MoNE do not satisfy mathematics teachers' needs in terms of content and duration.

Most of the studies about the effectiveness of in-service education programs in Turkey have collected their data through surveys (Baştürk, 2012; Boydak-Özan \& Dikici, 2001; Gültekin, Çubukçu, \& Dal, 2010; Kıldan \& Temel, 2008; Öztürk-Akar, 2007; Yılmaz \& Kocasaraç, 2010). Moreover, some studies have aimed to analyze the current situation via surveys and interviews (Akpınar, 2003; Demirkol, 2010; Küçüksüleymanoğlu, 2006). The common feature of the aforementioned studies is that they focused on the needs and expectations of teachers through surveys and interviews. Education Reform Initiative (ERI/ERG) (2015), using the data collected from 1700 teachers who stated the lack of in-service education offered by the MoNE in terms of the content and the quality, recommended that in-service trainings should be school based.

Tanriverdi and Gunel (2012) found that teachers tend to resist to change due to their inadequate classroom practices, lack of conceptual knowledge and classroom management problems and suggested longitudinal studies blended with on-site support where teachers and researchers co-teach in real classroom environments. In support of these findings, other studies (i.e., Doğan, Çakıroğlu, Çavuş, Bilican, \& Arslan, 2011; Yiğit \& Altun, 2011) suggested that teachers should be supported in their classroom practices after in-service education programs. Considering the findings of the research around the world (e.g., Bryk et al., 2015; Coburn \& Penuel, 2016; Geiger, Muir, \& Lamb, 2016; Penuel et al., 2011; Steinberg, Empson, \& Carpenter, 2004), therefore, it is perspicuous that in-service education programs in Turkey should be based on teacherresearcher collaboration in school settings, with on-going supports especially when implementing new educational approaches since they face to confusion of "old-new" dilemma (Toluk-Uçar \& Demirsoy, 2010). Thus, this study focuses on professional collaboration with teachers in their teaching environment. The research questions are: 
1. What changes occur in teachers' pedagogies in the in-service training program supported by on-the-job visits (ongoing support)?

2. What are the profound factors for teacher change?

\section{METHOD}

As in the studies that have given teachers on-site support during in-service education programs (Akkus \& Hand, 2011; Fennema, 1997; Omar, 2004; Pennington, 1995), in this study as well, the processes experienced and practiced by the teachers were observed to analyze the development and change in the teachers' pedagogies. Thus, the pedagogical changes the teachers went through were observed via classroom practices and pedagogical discussion sessions conducted throughout the study, which examined teachers' pedagogical change depending on on-site support during teaching. Therefore, to answer the research problems, we conducted pedagogical discussions before and after the lessons, observations in the classrooms and interview with the teachers before and after the study. In the research, we focused on teachers' classroom practices and how they changed their classroom practices depending on professional support rather than what they learned. Since this change process is directly related to teachers' learning processes, a case study model was chosen to inquire the nature of teachers' pedagogical change processes (Glesne, 1999). In order to answer the research questions, this case study was organized as a longitudinal study. Further, each teacher had a unique change process which made us to give individual classroom support. Therefore, in this study each teacher was accepted as a case and since each teacher had a different change process within his or her own pedagogy, as Yin (1984) mentioned, embedded single case study was suited for this research.

Table 1. Teachers' information

\begin{tabular}{|c|c|c|c|c|}
\hline Teacher & Gender & Degree & Major & Teaching exp. \\
\hline Unzile & Female & B.Sc. & Primary School Teaching & 16 years \\
\hline Sukriye & Female & B.Sc. & Elem. Math Teaching & 21 years \\
\hline Hayriye & Female & M.Ed. & Elem. Math Teaching & 16 years \\
\hline Emine & Female & M.Ed. & Elem. Math Teaching & 9 years \\
\hline Serkan & Male & B.Sc. & Elem. Math Teaching & 7 years \\
\hline
\end{tabular}

The study was set up as a professional development program with the teachers who were willing to change their habits of classroom practices. The participants of the study were from the northwest region of Turkey teaching at public schools (Table 1). The teachers' teaching experiences ranged from 7 years to 21 years. Unzile had changed her teaching level from primary school to middle school (5 to 8 grades) within the last few years before the study. The study started with a workshop where we had discussions about teachers' perceptions of learning, teaching and their classroom practices. During the workshop, the teachers had the chance to become students in a lesson on Non-Euclidean Geometry after which a pedagogical discussion was held. At the end of the workshop, the teachers were asked to plan what kind of pedagogical changes they wanted to make and what kind of classroom practices they wanted to do during the study.

It is often mentioned in teacher change studies that the duration of collaboration with teachers increases the effectiveness of the study (Franke, Fennema, \& Carpenter, 1997). This current study lasted for six months. Consequently, the process of teachers' professional development was organized as a series of on-site visits that gave the teachers the opportunity to reflect on their classroom practices. The visits were conducted by two researchers at the same time or at different times on a weekly-base schedule as much as possible. That is, they were contacted for classroom observation each week; however, sometimes due to their schools' schedules, their personal plans, or weather conditions, either visits or observations were not able to be conducted. Also, some of the visits were not ended up with classroom observation. To illustrate, Unzile was visited 11 times and observed 7 times because, for example, she asked for sample implementation at one of the visits and there was a school-base central exam at another visit. Therefore, the number of visits and observations was not the same for all the teachers. Each visit roughly had the following structure: 1) talking about teacher's pedagogical goals; 2) classroom observation; 3) reflecting on the classroom practice; and 4) setting a new goal for the following week (see Table 2). As can be seen in the table, the teachers identified different pedagogical goals during the study depending on their needs. For instance, a teacher might want to discuss a mathematical concept and another teacher might wish to co-teach with the researcher(s). Each lesson was video- and/or audio-taped. At the end of every visit, we had pedagogical discussions with the teachers and took field reports. In the pedagogical discussions, there was no aim to introduce new teaching methods or techniques. The role of the researchers was to open discussion headings/topics that were identified in the classrooms and to help teachers determine feasible pedagogical goals according to their classroom settings. Another role of the 
researchers was to support the teachers to overcome the problems they faced via co-teaching. Therefore, the researchers had the participant-observer position during the study which provided "the opportunity for acquiring the status of "trusted person"' (Glesne, 1999, p. 43).

Table 2. A sample for pedagogical goals of the teachers for the first six visits

\begin{tabular}{|c|c|c|c|c|c|}
\hline Order of visits & Unzile & Sukriye & Hayriye & Emine & Serkan \\
\hline 1 & not specified & st-st interaction & not specified & st-st interaction & not specified \\
\hline 2 & st-st interaction & st-st interaction & $\begin{array}{l}\text { listen to the } \\
\text { students }\end{array}$ & st-st interaction & st-st interaction \\
\hline 3 & st-st interaction & st-st interaction & $\begin{array}{l}\text { listen to the } \\
\text { students }\end{array}$ & $\begin{array}{c}\text { emphasis on } \\
\text { conceptual } \\
\text { understanding }\end{array}$ & using student ideas \\
\hline 4 & st-st interaction & st-st interaction & $\begin{array}{l}\text { listen to the } \\
\text { students }\end{array}$ & $\begin{array}{c}\text { emphasis on } \\
\text { conceptual } \\
\text { understanding }\end{array}$ & $\begin{array}{c}\text { make students } \\
\text { think } \\
\text { deeply }\end{array}$ \\
\hline 5 & $\begin{array}{l}\text { listen to the } \\
\text { students }\end{array}$ & st-st interaction & $\begin{array}{l}\text { listen to the } \\
\text { students }\end{array}$ & ask questions & ask questions \\
\hline 6 & st-st interaction & st-st interaction & $\begin{array}{l}\text { listen to the } \\
\text { students }\end{array}$ & ask questions & mixed \\
\hline Total number of visits & 11 & 15 & 16 & 25 & 15 \\
\hline
\end{tabular}

\section{Data Analysis}

At the end of the study, the data set consisted of video and audio recordings of classroom implementations, audio records of discourses on pedagogical discussions and on-site observation notes. To make a holistic analysis of the data and to identify unique features of each teacher's change process, content and discourse analyses were conducted in this study. The teachers' pedagogical practices were successive based on pedagogical debriefing sessions built upon each other. In order to match the pedagogical goals and their enactments, Reformed Teaching Observation Protocol (RTOP) was used (Sawada, Piburn, Falconer, Turley, Benford, \& Bloom, 2000) that draws on the standards for teaching science and mathematics (NCTM, 1991, 2000; NRC, 1996). The short version of RTOP modified by Akkus and Hand (2011), Martin and Hand (2009) and Gunel, Akkus, Ozer-Keskin, and Keskin-Samanci (2013) consisted of 17 items, rated from 0 (not observed) to 4 (very descriptive), with four sub-categories being constructed: Student Voice, Teacher's Role, Problem Solving and Reasoning, and Questioning (see Appendix). These categories were aligned with the teachers' pedagogical goals. The RTOP sub-categories were defined as follows: (a) Student Voice: students share and discuss their ideas without being judged by the teacher; (b) Teacher's Role: teacher takes more listener position rather than explaining things; (c) Problem Solving and Reasoning: teacher encourages students to take the responsibility of problem solving process and asks for justification for their asserted ideas; and (d) Questioning: teacher asks thought provoking questions to get students' alternative ways of thinking.

Having finished the analysis, the implementation levels at each sub-category were delineated using the studies conducted by Akkus and Hand (2011) and Martin and Hand (2009), which are exploring (0 - 1 scores), developing (1 - 2 scores), changing (2 - 3 scores) and practicing (3 - 4 scores) that put longitudinal progress of the teachers. Briefly explained, a teacher at the exploring level shows some hesitations in implementation and easily returns to the old practices. Developing level of implementation means that teachers are open to try new pedagogical approaches, yet they tend to go back to their old teaching. Moreover, changing level of implementation shows high willingness of putting new pedagogical approaches into practice yet there are still few returns to the old teaching during specific issues. Lastly, a teacher at the practicing level has overcome several obstacles and made the new ways of teaching his/her daily routine. RTOP scores were assigned by the researchers first at the end of the observations and second after watching the videos. The match between the first and the second scorings ranged from $75 \%$ to $90 \%$. The match of the observers' scorings, on the other hand, ranged from $85 \%$ to $95 \%$. Therefore, to reconcile the controversial matches, the videos were watched together by the two authors and reached the consensus for all the RTOP scores. To ensure the validity and reliability of the study, several precautions were taken. First of all, through a prolonged involvement, we created a trusted relationship with the teachers. This provided us the opportunity to observe their natural classroom practices. Moreover, triangulation technique was used for data collection (e.g., live observation, video or audio recordings, interview with the teachers). In addition, both researchers took descriptive and reflective field notes after each visit and compared them on weekly-base meetings. 


\section{FINDINGS}

The results of the RTOP scores and the preliminary analysis of the pedagogical debriefing sessions showed that the progress of the teachers had various characteristics in terms of enacting their pedagogical goals set during the study (see Figure 1 a-e). For example, while Serkan tried to practice on teacher role for the first few weeks, Emine was cautious about how to start a change in her classroom, which made her to take small steps at a time. Furthermore, the teachers reached the different levels of pedagogical implementations measured by the RTOP scores. We can see in the figure that the teachers developed their teaching based on their pedagogical goals identified each week. To illustrate, Serkan was very cautious in changing his pedagogy at the beginning of the study. Therefore, as other teachers, he did not develop for the first three observations. The first change in his pedagogy was related to student-student interaction. Without altering his role in the classroom, he tried to increase student voice by asking thought provoking questions and pushing students to justify their problem-solving strategies. At the fourth observation, there were increases in Serkan's all subcategories of RTOP. Since this changing attitude continued until the end of the study, Serkan was at the changing level. Similarly, Emine tried to develop student-student interaction in her classroom during the first two observations. At the same time, she was eager to increase her conceptual understanding of mathematical concepts in order to lead classroom discussions better. This was depicted in Figure 1d as the fourth observation, which shows a holistic increase in Emine's implementation. However, the following week, she focused on her role in the classroom that caused her to loosen other pedagogical aims (student voice, problem solving, and questioning). Because Emine was very decisive about her pedagogical progress as the increasing trend of her RTOP scores demonstrates, she was labeled at the changing level.

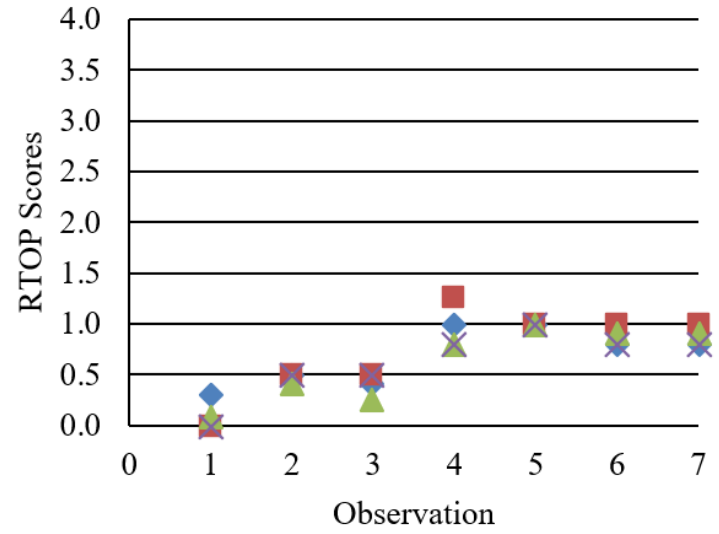

- St Voice $\quad$ Teacher Role $\triangle$ Prob Solv $\times$ Q.ing a) Unzile (Exploring)

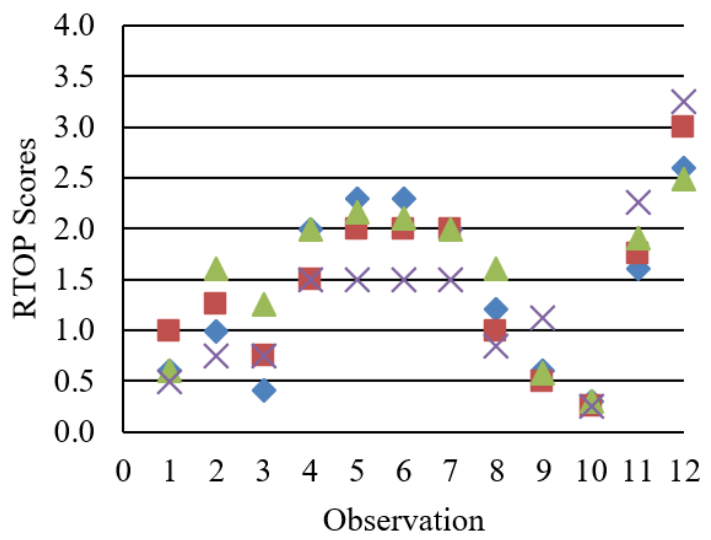

- St Voice $\square$ Teacher Role $\triangle$ Prob Solv $\times$ Q.ing c) Hayriye (Changing)

Figure 1. a-e Teachers' RTOP scores for sub-categories

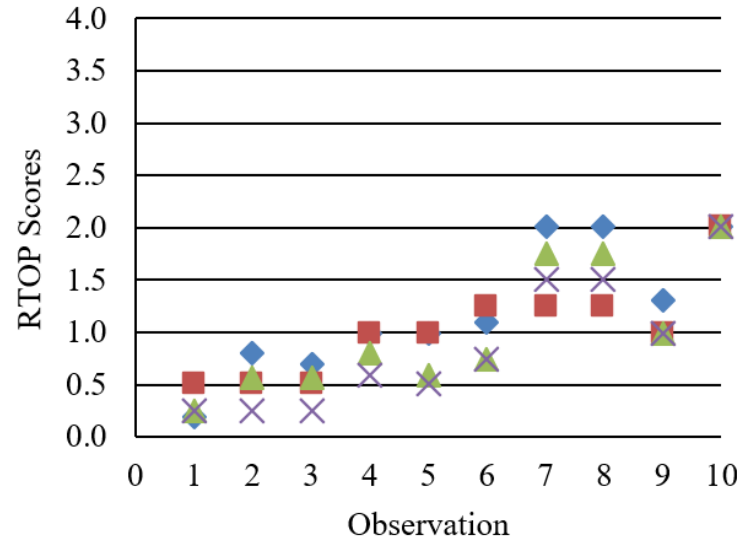

- St Voice $\square$ Teacher Role $\triangle$ Prob Solv $\times$ Q.ing b) Sukriye (Developing)

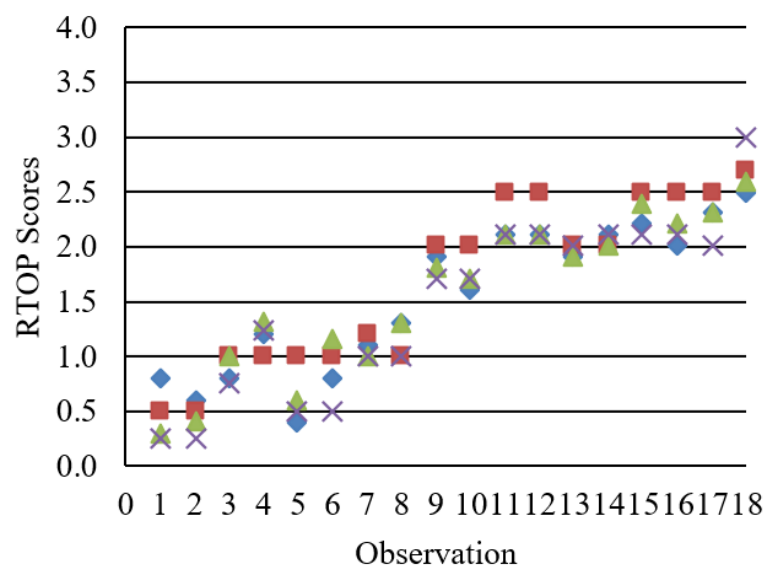

$\diamond$ St Voice $\square$ Teacher Role $\triangle$ Prob Solv $\times$ Q.ing d) Emine (Changing) 


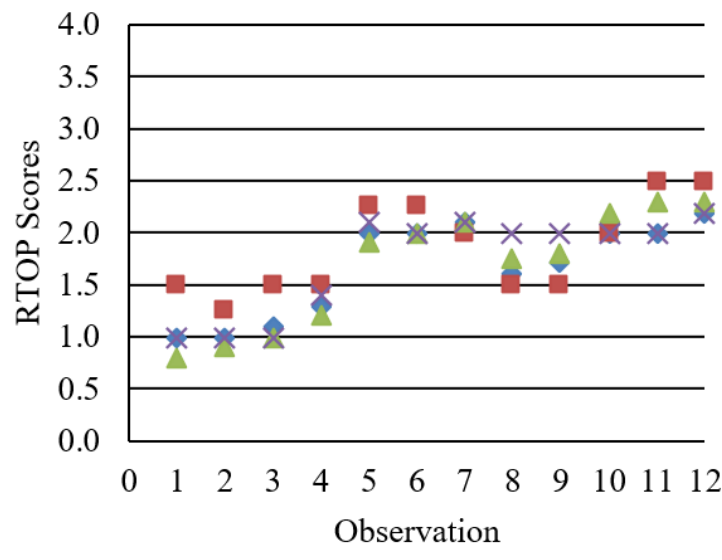

$\diamond$ St Voice $\square$ Teacher Role $\triangle$ Prob Solv $\times$ Q.ing

e) Serkan (Changing)

Figure 1 (continued). a-e Teachers' RTOP scores for sub-categories

The results of the study led to three assertions. One is related to the pedagogical discussions made before and after implementations. These discussions helped the teachers critique their own current pedagogical classroom practices and their efforts in the new goals. The second one is related to co-teaching and the sample implementations by the researchers. This approach showed the teachers that their pedagogical goals were feasible in their classroom culture as well. Third, the teacher tended to believe that radical changes were possible in their classrooms as they saw drastic shifts in their students' behaviors (cognitive and physical).

\section{Assertion 1: Pedagogical Discussions Seemed to be a Lighthouse for the Teachers to be Aware of their Own Actions in the Classroom}

Even though the teachers resisted to open themselves at a first glance, they began to benefit from pedagogical discussions due to the non-threatening environment. As researchers we paid special attention to not digging out the negative sides of the teachers' implementations. Instead, we created an atmosphere where (in which) they developed an awareness of their classroom practices. For example, Emine complained about her students' behavioral issues and their dependence on her in terms of problem solving. Having analyzed her classroom practice together, she questioned herself that "Perhaps, I am the one who encourage them to behave like this. I can't reach all the students except the ones at the front desks."

The teachers benefitted from the pedagogical discussions in terms of developing their conceptual knowledge of mathematics. Even Serkan, although he thought that he had good mathematical knowledge, needed to discuss conceptual side of mathematical knowledge. This helped the teachers open themselves for change and thinking the quality of students' learning.

\section{Assertion 2: The Teachers Needed Sample Implementations to See that it is Doable in their Classroom Culture as well}

Since the teachers had negative attitudes towards in-service training programs in general, they were not apt to implement what was offered by the researchers. That is, they were very skeptical to phrase mongering about teaching and learning mathematics. "Most in-service education programs are the same; boring, theoretical book sentences, presented by 'knowledgeable' university professors" (Unzile; First school visit to invite for participation). Serkan was very cautious when implementing an advice from the researchers even if he thought that it would be beneficial for his class. In these times, he asked for sample lessons or co-teaching from the researchers. Being in the class with the teachers was very important because they felt that they needed someone ready in the classroom if they would face some problems. "I was feeling that I lack of something pedagogically. I felt that I must do something to be beneficial for the students. ... We'll be together in the class, right?" (Sukriye; First meeting for the first implementation). The teachers tended to try their pedagogical goals especially right after the sample implementations. For example, Emine expressed that "after watching 
Recai conducting mathematical discussion with my students, I've tried to implement my pedagogical goals with passion" (Post-interview).

\title{
Assertion 3: Seeing Students' Changing Behaviors in the Classroom was a Driving Force to Shift Pedagogy
}

The main characteristic of the students in the teachers' classrooms was that the students neither trusted each other nor wanted to work together. Moreover, the teachers believed that "wrong learning becomes permanent." For example, Sukriye stated that "If I got the correct answer, I continued with explanation. This blocked the process [of argumentation]. However, you [the researcher] insisted on students' justifications about their correct and wrong answers." The teachers tried to change their pedagogical practices step by step after seeing the effect of the previous one. For instance, Serkan summarized his change process as:

\begin{abstract}
I've noticed that my students can look at the issues critically. I realized that they can express themselves comfortably when they first write. In the past, they used to forget the beginning of the lesson. But now, they can easily recover the lesson. I think we had them to think more and critique each other. Since they listened to each other carefully, there was a healthy communication among them.
\end{abstract}

Moreover, the teachers stated that their students created a new classroom culture. To illustrate, Sukriye expressed that "These kids started to listen to each other and to work together on something. And I realized that they have various ideas, I liked it." For the teachers sometimes, seeing was believing. That is, Emine for example, declared that "

\begin{abstract}
After watching Recai conducting mathematical discussions with my students, I have tried to implement my pedagogical goals with passion and through believing that I can do this. Because, Recai valued the students'ideas and I saw the light in the students' eyes.... I have also noticed that the students can't learn not because of their incompetencies but due to my beliefs in them. They can think mathematically, they really do.
\end{abstract}

Moreover, students' mathematical thinking and achievement had an impact on the teachers' change. While Hayriye pointed out "drastic changes in expressing their ideas in the discussions," Sukriye noticed that the students' misbehaviors extinguished and they focused on conceptual discussions (A student: Now, we have to pursue Berat. Berat, say your justification so let us think about it).

\section{DISCUSSION}

Developing teachers' pedagogical competencies is a hard process and takes a long time (Castle \& Aichele, 1994; Harris et al., 2012; Knight et al., 2015; Tanriverdi, Kurt, \& Soysal, 2014). Every teacher sets up own classroom settings according to own understanding of learning and teaching. However, during the process of change (and implementation of new approaches), there are some challenges out of teachers' control. Contrary to the common view in society that the only responsibility of teachers in schools is "teaching the subjects", teachers try hard to raise individuals who both are competent academically and have good manners in relationships with ethical issues. With the total about 800 hours of data collection process in the schools, we experienced and witnessed that the teachers in this study cared their students and wrestled with many issues.

We noticed that there was a unique driving force for every teacher to take a step for change. The teachers moved to change on their own paces whenever they felt ready. For example, Emine mentioned that she wanted to reach every student in her classrooms and to become assertive in her teaching ( $I$ want to restructure my lessons based on not only the procedural but also the conceptual dimensions of mathematics). During the project she declared that she felt lucky because "it seems that I am taking special tutoring sessions from a university professor" (Debriefing session). Emine was really aware of her classroom practices by which she had been disturbed, which was the cornerstone of her enterprise for pedagogical change. The change process of Emine, as Pennington (1995) and Castle and Achiele (1994) argued, was related to the awareness of her pedagogical needs. Moreover, Emine was dissatisfied with her mathematical knowledge and lack of teaching methods that encouraged her to participate the project and to change. Similarly, Reid and Zack (2010) mentioned that teachers' dissatisfaction of own knowledge (e.g., content knowledge) pushed them to change.

Serkan was very assertive about his mathematical knowledge which held him to break down the walls between the researchers and him. He allegedly challenged the researchers to find his mathematical mistakes 
in the classroom. Yet, as researchers we always tried to give a message that "we are here to learn together not to judge the teacher." Serkan was willing to open himself after one of the researchers implemented a lesson in the classroom. Serkan's discourses started to change from "discussion with these kids is a cause of cancer" and "challenge and time consuming" to "these implementations are feasible in my classroom too, what about adding this..." and "I couldn't guess this boy has such a conceptual understanding". Therefore, his resistance to try something new broke down after the sample lesson conducted at the sixth week. Serkan tried to change his classroom practice, yet he oscillated about his role in the classroom.

Even though Sukriye willingly wanted to change her classroom practices, it was hard for her to discuss about her teaching at first. While making pedagogical evaluation, she always felt to defense herself by blaming either students and parents or the education system. At a meeting, the researchers shared their observation about why the students were not listening to each other which was Sukriye's complaint about her students. When the researchers reported that "you are the authority in the class and the students expect you to approve their ideas as true or false. Thus, there is no need for them to listen to their friends." For the following lesson, Sukriye had a goal for not approving students, and this time we watched her lesson video together and she realized her own real habits of classroom practices. The breaking point for Sukriye was her realistic evaluation of own classroom practices (Chazan \& Ball, 1995; Goldsmith \& Schifter, 1997).

Hayriye thought that she could renew her pedagogical practices and try something new since our first visit. She expressed that she implemented problem-solving approach during her first years of professional teaching; however, because of some factors (curriculum load, lack of support from principals and colleagues), she could not have been implementing such teaching. Even though Hayriye missed the focus of pedagogical discussions, the researchers tried to steer the discussion to the focus. And these pedagogical discussions were the driving force for Hayriye's change yet she couldn't make them part of her pedagogical practice. She started to make the changes in her classroom practices when the researchers pointed out the shortage in the classroom and offered feasible methods for her classrooms. Hayriye always went back to her "old good implementations". The thought of "I have already been doing this" and misalignment of pedagogical skills might hinder her to carry this new learning journey further and prevent sustainable improvement.

Unzile always expected the researchers to give her material and activity examples about the subjects. Even though the researchers explained that it was not the aim of the project she insisted on asking for it. Instead of focusing on her pedagogical practices in her classroom, she always tried to take the discussions to "such implementations were not applicable in public schools." After an example of implementation by one of the researchers, she admitted that she could not teach as she wanted; yet, she could not get away from her teaching habits either. She always complained about the education system, her school administrators, students and parents that prevent her to implement new style of teaching. This thought hindered her change process. Therefore, for Unzile, outside factors were obstacles to try new things (Akkus \& Hand, 2011; Alger, 2009; Goos \& Geiger, 2010).

Overall, there were three teachers in changing process according to the RTOP scores (Hayriye, Emine and Serkan). On the other hand, there were three hinders for them not putting changing pedagogies into practice. While Hayriye could not align her pedagogical skills in accordance with pedagogical goals, Serkan oscillated about his role in the classroom while trying to change his classroom practices. Emine, on the other hand, struggled in conceptual mathematical knowledge in putting this change into practice.

The participant teachers had some common pedagogical features depicted in their classrooms. For example, since all the teachers were concerned about the curriculum and took the responsibility of students' learning, they struggled to integrate their pedagogical goals. During the pedagogical discussions, we as the researchers tried to make this visible for the teachers so that they became conscious about their roles in the classroom (Castle \& Aichele, 1994; Goos \& Geiger, 2010). Several resources (e.g., Mewborn, 2003; NCTM, 2000; Schifter, 1998) stress this notion that the flexibility of teaching strategies is related to teachers' conceptual understanding of mathematics, which is the key to manage to help students construct deep mathematical understanding. Moreover, the teachers did not allow students to make mistakes. This case was observed when the teacher took the pen and continued solving a problem while a student was leaning to wrong solution (Unzile and Sukriye); when they did not give students the opportunity to explain their ideas (Did we learn this? No, we've learned ...) while students were sharing wrong information (Serkan, Emine, Sukriye, Unzile and Hayriye); when the teacher warned students by "Look my child, if you don't listen to this one, you won't be able to do the next one" (Sukriye). Upon sharing this observation with the teachers, they all had the excuse that "wrong learning becomes permanent, you can't change it later." This belief hinders teachers to listen to their students' ideas and structure the lesson on those ideas (Guskey, 1986). It was observed that conducting 
classroom implementation and pedagogical discussions that affected the teachers' beliefs encouraged them to change classroom practices. Nelson (1997) points out that through PD programs, teachers tend to shift their perceptions about students' abilities of learning mathematics.

Another pedagogical goal was to change their questioning habits. The teachers felt the need for change in questioning at different times. For example, Emine wanted to change her questioning habits at the second week, Serkan at the fifth week, Hayriye at the eighth week, Sukriye at the tenth week depending on the pedagogical needs based on the struggles faced in the classroom implementations. Cohen and Barnes (1993) mentioned that teachers who have efficient content knowledge and want to make connections among the concepts may feel the need to build different strategies in their implementations. Serkan and Emine always had some focused queries during the pedagogical discussions.

To sum up, while the teachers' awareness of their pedagogical needs (e.g., conceptual knowledge, questioning), seeing drastic shifts in their students' learning behaviors, and realistic evaluation of their own classroom practices opened avenues for pedagogical changes, their attitudes of blaming outside factors for implementing a new pedagogical approach and not allowing students to make mistakes (i.e., wrong learning becomes permanent) hindered the shift, and their misalignment of pedagogical needs prevented sustainable improvement. However, sample implementations and pedagogical discussions helped the teachers plan feasible implementations that suited their classroom environment. Therefore, the factors driving teacher change are bidirectional such that internal and external domains are interconnected (Clarke \& Hollingsworth, 2002; Wilkie, 2019).

\section{CONCLUSIONS}

There are three intriguing conclusions out of this study. The first one is that researchers should not behave as the "knower" of everything about teaching and learning. As much as we, as researchers, get rid of our "knower the academic" position, teachers tend to become part of the project. Therefore, it is clear that teachers should go beyond traditional perception of in-service training and take part in their own learning processes and should not be seen only as practitioners (Check, 1997). Secondly, in-service trainings aiming to increase the professional development of teachers through on-the-job visits provide the opportunity for teachers to develop themselves according to their individual needs. Teachers may encounter problems arising from the school culture and physical environment as well as problems arising from their pedagogy, conceptual knowledge, and pedagogical content knowledge. These issues can be overcome through the collaboration of teachers and researchers in classroom settings (Ball \& Forzani, 2010; Diezmann \& Watters, 2015). Moreover, such experiences have also been educational for researchers because everything is not as seen from the outside. The researchers have seen more clearly the pressures on the teachers and tried to reveal the realistic factors affecting their changes. Therefore, it is important for the researchers of professional development to eyewitness such challenges in school settings in order to understand and help teachers take feasible steps to implement new approaches. Third, not the least, is the fact that another teacher conducts the lesson in the teachers' classrooms gives them the opportunity to observe the performance of different practitioners in the same school culture. These implementations along with the pedagogical discussions help both teachers and researchers reflect on their own practices in a safe zone.

At the end of the research, the driving forces that caused the pedagogical change of the participant teachers were determined as sample implementations and on the job trainings. While sample practices help teachers create negotiation processes with their own practices, the most important role of on-the-job visits is to accelerate teachers' change processes with sample practices and discussions. Teachers alter their habits, attitudes and beliefs along with their pedagogies in the process of change. Therefore, the change of teachers is a long-term process (Günel \& Tanriverdi, 2014; Pennington, 1995). It is quite shallow to determine the effectiveness and usefulness of the subjects discussed in the in-service trainings at the beginning and end of the one-shut programs through surveys and to form new teacher education policies. Therefore, it is quite optimistic to determine the results of the trainings that have not yet met with the student in the classroom environment immediately after the training. Since the practice of each teacher will vary according to the school culture, evaluation of the studies with teachers must be in schools, otherwise the teacher's belief in students and school will be left aside. Even though it is known that the time devoted to in-service training in Turkey is more than most of the world, the educational process is not considered effective. Günel and Ceyhan (2016) argue that a long-term transformation process is required for the adaption and internalization of innovations in in-service trainings by teachers. 
There were some limitations in this study. First of all, due to teachers' perceptions about in-service education programs, it was hard to access volunteered teachers. In order to convict them to participate such programs, As House (1994) emphasizes, in-service trainings should be held near teachers' schools and there should be someone to collaborate in practicing the approaches they have learned in the PD programs. The opportunities and environments should be created for teachers to participate in in-service trainings during the semester, and to reduce the material and moral burden. Therefore, teachers may be encouraged to participate in collaborative projects during working hours as Wilkie (2019) emphasized by attributing to Johnson (1996) that learning of teachers should be the on-going process of the school environment. Another limitation of this study was the number of researchers. There were only two researchers conducting this study. Such shortage made difficult, for example, to visit every teacher each week and to analyze the data weekly. These kinds of studies are generally conducted by a research team consisting of several experts in different areas.

\section{Disclosure statement}

No potential conflict of interest was reported by the authors.

\section{Notes on contributors}

Recai Akkuş - Bolu Abant Izzet Baysal University, Turkey.

Melisa Karakaya - Bolu Abant Izzet Baysal University, Turkey and Development Workshop Cooperative, Turkey.

\section{REFERENCES}

Akkuş, R., \& Hand, B. (2011). Examining teachers' struggles as they attempt to implement dialogical interaction as part of promoting mathematical reasoning within their classrooms. International Journal of Science and Mathematics Education, 9(4), 975-998. https://doi.org/10.1007/s10763-010-92668

Akpınar, Y. (2003). Öğretmenlerin yeni bilgi teknolojileri kullanımında yükseköğretimin etkisi: İstanbul okulları örneği [The effect of higher education on the use of new information technologies by teachers: Istanbul schools example]. The Turkish Online Journal of Educational Technology, 2(2), 79-96.

Alger, C. L. (2009). Secondary teachers' conceptual metaphors of teaching and learning: Changes over the career span. Teaching and Teacher Education, 25(5), 743-751. https://doi.org/10.1016/j.tate.2008.10.004

Babadogan, C., \& Olkun, S. (2006). Program development models and reform in Turkish primary school mathematics curriculum. International Journal for Mathematics Teaching and Learning, 1(1), 1-6.

Bağcı, N., \& Şimşek, S. (2000). Milli Eğitim personeline yönelik hizmet içi eğitim faaliyetlerine genel bir bakış [An overview of in-service training activities for National Education personnel]. Millî Ĕgitim Dergisi, 146, 9-12.

Ball, D. L., \& Forzani, F. M. (2010). What does it take to make a teacher? Phi Delta Kappan, 92(2), 8-12. https://doi.org/10.1177/003172171009200203

Ball, D., \& Forzani, F. M. (2009). The work of teaching and the challenge for teacher education. Journal of Teacher Education, 60(5), 497-511. https://doi.org/10.1177/0022487109348479

Baştürk, R. (2012). İlköğretim öğretmenlerinin hizmetiçi eğitime yönelik algı ve beklentilerinin incelenmesi [Examining the perceptions and expectations of primary school teachers towards in-service education]. Hacettepe Üniversitesi Eğitim Fakültesi Dergisi,42(42), 96-107.

Boydak Özan, M., \& Dikici, A. (2001). Hizmet içi eğitim programlarının etkililiğinin değerlendirilmesi [Evaluation of the effectiveness of in-service training programs]. Frrat Üniversitesi Sosyal Bilimler Dergisi, 11(2), 225-240.

Bryk, A., Gomez, L., Grunow, A., \& LeMahieu, P. (2015). Learning to improve: How America's schools can get better at getting better. Boston, MA: Harvard Education Publishing.

Castle, K., \& Aichele, D. B. (1994). Professional development and teacher autonomy. In D. Aichele and A. Coxford (Eds.), Professional development for teachers of mathematics: 1994 Yearbook (pp. 1-8). Reston, VA: NCTM. 
Chazan, D., \& Ball, D. (1995). Beyond Exhortations Not To Tell: The Teacher's Role in Discussion-Intensive Mathematics Classes. NCRTL Craft Paper 95-2.

Clark, C. M., \& Peterson, P. L. (1984). Teachers' thought processes. Occasional paper no. 72. Michigan: Michigan State University

Clarke, D. (1994). Ten key principles from research for the professional development of mathematics teachers. In D. Aichele and A. Coxford (Eds.), Professional development for teachers of mathematics: 1994 Yearbook (pp. 37-48). Reston, VA: NCTM

Clarke, D., \& Hollingsworth, H. (2002). Elaborating a model of teacher professional growth. Teaching and Teacher Education, 18(8), 947-967. https://doi.org/10.1016/S0742-051X(02)00053-7

Coburn, C., \& Penuel, W. (2016). Research-practice partnerships: Outcomes, dynamics, and open questions. Educational Researcher, 45(1), 48-51. https://doi.org/10.3102/0013189X16631750

Cohen, D. K., \& Barnes, C. A. (1993). Conclusion: A new pedagogy for policy. In D. K. Cohen, M. W. McLaughlin and J. E. Talbert (Eds.), Teaching for understanding: Challenges for policy and practice (pp. 240-275). San-Fransisco: Jossey-Bass.

Cohen, D. K., Raudenbush, S. W., \& Ball, D. L. (2003). Resources, instruction, and research. Educational Evaluation and Policy Analysis, 25(2), 119-142. https://doi.org/10.3102/01623737025002119

Cooney, T. J. (1994). Teacher education as an exercise in adaptation. In D. Aichele and A. Coxford (Eds.), Professional development for teachers of mathematics: 1994 Yearbook (pp. 9-22). Reston, VA: NCTM

Demirkol, M. (2010). İlköğretim okullarında öğretmenlere yönelik okul-temelli hizmetiçi eğitim etkinliklerinin değerlendirilmesi [Evaluation of school-based in-service training activities for teachers in primary schools]. Milli Eğitim Dergisi, (188), 158-173.

Doğan, N., Çakıroğlu, J., Çavuş, S., Bilican, K., \& Arslan, O. (2011). Öğretmenlerin Bilimin Doğası Hakkındaki Görüşlerinin Geliştirilmesi: Hizmetiçi Eğitim Programının Etkisi [Improving Teachers' Views on the Nature of Science: The Effect of In-Service Training Program]. Hacettepe Üniversitesi Eğitim Fakültesi Dergisi, 40, 127-139.

Ĕğitim Reformu Girişimi (ERG) (2015). Eğitim İzleme Raporu 2014-2015 [Training Monitoring Report 20142015]. İstanbul.

Eraslan, A. (2009). Finlandiya'nın PISA'daki başarısının nedenleri: Türkiye için alınacak dersler [Reasons for the success of Finland's PISA: lessons to be learned for Turkey]. Necatibey Eğitim Fakültesi Elektronik Fen ve Matematik Eğitimi Dergisi (EFMED), 3(2), 238-248.

Even, R. \& Tirosh, D. (2002). Teacher knowledge and understanding of students' mathematical learning. In L. D. English (Ed.), Handbook of international research in mathematics education, (pp. 219-240). Mahwah, NJ: Lawrence Erlbaum.

Franke, M. L., Fennema, E., \& Carpenter, T. (1997). Teachers creating change: Examining evolving beliefs and classroom practice. In E. Fennema and B. Nelson (Eds.). Mathematics teachers in transmission (pp. 255-282). Mahwah, NJ: Lawrence Erlbaum.

Geiger, V., Muir, T., \& Lamb, J. (2016). Video-stimulated recall as a catalyst for teacher professional learning. Journal of Mathematics Teacher Education, 19, 457-475. https://doi.org/10.1007/s10857-015-9306-y

Glesne, C. (1999). Becoming qualitative researchers: An introduction (2nd Ed.). New York, NY: Longman.

Gökmenoğlu, T., Clark, C. M., \& Kiraz, E. (2016). Professional development needs of Turkish teachers in an era of national reforms. Australian Journal of Teacher Education, 41(1), 112-125. https://doi.org/10.14221/ajte.2016v41n1.7

Goldsmith, L., \& Schifter, D. (1997). Understanding teachers in transition: Characteristics of a model for developing teachers. In E. Fennema \& B. S. Nelson (Eds.), Mathematics teachers in transition (pp. 1954). Mahwah, New Jersey. Lawrence Erlbaum Associates.

Goos, M., \& Geiger, V. (2010). Theoretical perspectives on mathematics teacher change. Journal of Mathematics Teacher Education, 13(6), 499-507. https://doi.org/10.1007/s10857-010-9166-4

Gültekin, M., Çubukçu, Z., \& Dal, S. (2010). İlköğretim öğretmenlerinin eğitim öğretimle ilgili hizmetiçi eğitim gereksinimleri [In-service training requirements of primary education teachers regarding education]. Selçuk Üniversitesi Ahmet Keleşoğlu Eğitim Fakültesi Dergisi, 29, 131-152.

Günel, M., \& Tanriverdi, K. (2014). In-service teacher training from international and national perspectives: The retention and loss of institutional and academic memories. Education and Science, 39(175), 73-94. https://doi.org/10.15390/EB.2014.2949 
Günel, M., Akkuş, R., Özer-Keskin, M., \& Keskin-Samanci., N. (2013). Improving Students' Conceptual Understanding of Science Through Argument Based Science Inquiry Implementations: A Case of Nationwide Professional Development Project. Paper presented at the 1st International Conference on Immersion Approaches to Argument-based Inquiry (ABI) for Science Classrooms, Busan, Korea. 4-7 February 2013.

Guskey, T. R. (1986). Staff development and the process of teacher change. Educational Researcher, 15(5), 512. https://doi.org/10.3102/0013189X015005005

Hand, B., Norton-Meier, L. A., Gunel, M., \& Akkus, R. (2016). Aligning teaching to learning: A 3-year study examining the embedding of language and argumentation into elementary science classrooms. International Journal of Science and Mathematics Education, 14(5), 847-863. https://doi.org/10.1007/s10763-015-9622-9

Harris, K. R., Lane, K. L., Graham, S., Driscoll, S. A., Sandmel, K., Brindle, M., \& Schatschneider, C. (2012). Practice-based professional development for selfregulated strategies development in writing: A randomized controlled study. Journal of Teacher Education, 63(2), 103-119. https://doi.org/10.1177/0022487111429005

Jones, D. (1997). A conceptual framework for studying the relevance of context to mathematics teachers' change. In E. Fennema \& B. Nelson (Eds.), Mathematics teachers in transmission (pp. 131-154). Mahwah, NJ: Lawrence Erlbaum.

Jones, G. A., Lubinski, C. A., Swafford, J. O., \& Thornton, C. A. (1994). A framework for the professional development of K-12 mathematics teachers. In D. Aichele \& A. Coxford (Eds.). Professional development for teachers of mathematics (pp. 23-36). Reston, VA: NCTM.

Kıldan, O., \& Temel, F. (2008). The effects of in-service training practices for preschool teachers in line with the constructivist approach to determine teachers' perceptions. Kastamonu Education Journal, 16(1), 25-36.

Knight, S. L., Lloyd, G. M., Arbaugh, F., Gamson, D., McDonald, S. P., Nolan, J., \& Whitney, A. E. (2015). School-Based Teacher Learning. Journal of Teacher Education, 66(4), 301-303. https://oi.org/10.1177/0022487115596828

Küçüksüleymanoğlu, R. (2006). In service training of ELT teachers in Turkey between 1998-2005. Uludag University Education Faculty Journal, 19(2), 359-369

Lesh, R. (2002). Research design in mathematics education: Focusing on design experiments. In L. English (Ed.), Handbook of international research in mathematics education (pp. 27-49). Mahwah: Lawrence Erlbaum Associates.

Llinares, S., \& Krainer, K. (2006). Mathematics (student) teachers and teacher educators as learners. In A. Gutie'rrez and P. Boero (Eds.), Handbook of research on the psychology of mathematics education: Past, present and future (pp. 429-459). Rotterdam, The Netherlands: Sense Publishers. https://doi.org/10.1163/9789087901127_016

Martin, A. M., \& Hand, B. (2009). Factors affecting the implementation of argument in the elementary science classroom. A longitudinal case study. Research in Science Education, 39(1), 17-38. https://doi.org/10.1007/s11165-007-9072-7

Mewborn, D. S. (2003). Teaching, teachers' knowledge, and their professional development. In J. Kilpatrick, W. G. Martin \& D. Schifter (Eds). A research companion to Principles and Standards for School Mathematics (pp. 45-52). Reston, VA: NCTM.

Ministry of National Education-MoNE (2012a). Milli Eğitim Bakanlı̆̆ -MEB (2012a).19.05.2012 tarihli "12 Yıllık Zorunlu Eğitime Yönelik Uygulamalar” konulu, B.08.0.ÖKM. O.OO-00.00/401 sayılı genelge [Instructions for the 12-Year compulsory education, document number B.08.0.ÖKM. O.OO-00.00/401]. Ankara: MoNE.

Ministry of National Education-MoNE (2012b). Meslekiçi eğitim ihtiyacını belirleme anketi genel değerlendirme sonuçları [The general results of survey for inservice education needs]. Ankara: MoNE.

National Council of Mathematics (NCTM) (1991). Principles and standards for school mathematics. Reston, VA: National Council of Teachers of Mathematics.

National Council of Teachers of Mathematics (NCTM) (2000). Principles and standards for school mathematics. Reston, VA: National Council of Teachers of Mathematics. 
National Research Council (NRC). (1996). National science education standards. Washington, DC: National Academic Press.

Nelson, B. S. (1997). Learning about teacher change in the context of mathematics education reform: Where have we come from? In E. Fennema \& B. S. Nelson (Eds.), Mathematics teachers in transition (pp. 315). Mahwah, NJ: Lawrence Erlbaum Associates

Omar, S. (2004). Inservice teachers'implementation of science writing heuristic as a tool for professional growth (Unpublished PhD dissertation). Ames: Iowa State University, USA.

Öztürk-Akar, E. (2007). Inservice training needs of biology teachers and observed local differences. Education and Science, 32(143), 68-79.

Pennington, M. C. (1995). The teacher change cycle. Tesol Quarterly, 29(4), 705-731. https://doi.org/10.2307/3588171

Penuel, W., Fishman, B., Cheng, B., \& Sabelli, N. (2011). Organizing research and development at the intersection of learning, implementation and design. Educational Researcher, 40(7), 331-337. https://doi.org/10.3102/0013189X11421826

Reid, D., \& Zack, V. (2010). Observing the process of mathematics teacher change-part 1. Journal of Mathematics Teacher Education, 13(5), 371-374. https://doi.org/10.1007/s10857-010-9158-4

Sawada, D., Piburn, M., Falconer, K., Turley, J., Benford, R., \& Bloom, I. (2000). Reformed Teaching Observation Protocol (RTOP) (ACEPT Technical Report No. IN00-1). Tempe, AZ: Arizona Collaborative for Excellence in the Preparation of Teachers.

Schifter, D. (1998). Learning mathematics for teaching: From a teachers' seminar to the classroom. Journal of Mathematics Teacher Education, 1, 55-87. https://doi.org/10.1023/A:1009911200478

Sherin, M. G., Sherin, B. L., \& R. Madanes (2000) Exploring diverse accounts of teacher knowledge. Journal of Mathematical Behaviour 18(2), 357-375. https://doi.org/10.1016/S0732-3123(99)00033-4

Simon, M. (1995). Reconstructing mathematics pedagogy from a constructivist perspective. Journal for Research in Mathematics Education, 26, 114-145. https://doi.org/10.2307/749205

Simon, M. (1997). Developing new models of mathematics teaching. In E. Fennema \& B. S. Nelson (Eds.), Mathematics teachers in transmission (pp. 55-86). Mahwah, NJ: Lawrence Erlbaum.

Sowder, J. T., Philipp, R. A., Armstrong, B. E., \& Schappelle, B. P. (1998). Middlegrade teachers' mathematical knowledge and its relationship to instruction: A research monograph. Albany: State University of New York Press.

Steinberg, R., Empson, S., \& Carpenter, T. (2004). Inquiry into children's mathematical thinking as a means to teacher change. Journal of Mathematics Teacher Education, 7(3), 237-267 https://doi.org/10.1023/B:JMTE.0000033083.04005.d3

Supovitz, J. A., \& Turner, H. M. (2000). The effects of professional development on science teaching practices and classroom culture. Journal of Research in Science Teaching, 37(9), 963-980. https://doi.org/10.1002/1098-2736(200011)37:9<963::AID-TEA6>3.0.CO;2-0

Swafford, J. O., Jones, G. A., \& Thornton, C. A. (1997). Increased knowledge in geometry and instructional practice. Journal for Research in Mathematics Education, 28, 467-483. https://doi.org/10.2307/749683

Sykes, G., Bird, T., \& Kennedy, M. (2010). Teacher education: Its problems and some prospects. Journal of Teacher Education, 61(5), 464-476. https://doi.org/10.1177/0022487110375804

Tanrıverdi, K., \& Gunel, M. (2012). Öğretmen pedagojisinde kritik sorun: Değişime karşı direnç [A critical problem in teacher pedagogy: Resistance to change]. In 10th National Conference of Science and Mathematics Education, Nigde, Turkey.

Tanrıverdi, K., Kurt, İ., \& Soysal, Y. (2014). Öğretmen mesleki gelişiminin anahtarl: pedagojik değişim [The key to teacher professional development: pedagogical change]. Öğretmen Dünyası, 414, 16-18.

Toluk-Uçar, Z., \& Demirsoy, N. H. (2010). Tension between old and new: Mathematics teachers' beliefs and practices. Hacettepe University Journal of Education, 39, 321-332.

Verschaffel, L., Greer, B., \& Torbeys, J. (2006). Numerical thinking. In A. Gutie'rrez and P. Boero (Eds.), Handbook of research on the psychology of mathematics education: Past, present and future, (pp. 51-82). Rotterdam, The Netherlands: Sense Publishers. https://doi.org/10.1163/9789087901127_004

Wallace, M., Cederberg, J., \& Allen, R. (1994). Teachers empowering teachers: a professional-enhancement model. In D. Aichele \& A. Coxford (Eds.), Professional development for teachers of mathematics: 1994 Yearbook (pp. 234-245). Reston, VA: NCTM. 
Walshaw, M., \& Anthony, G. (2008). The teacher's role in classroom discourse: A review of recent research into mathematics classrooms. Review of Educational Research, 78(3), 516-551. https://doi.org/10.3102/0034654308320292

Wasserman, N. H., \& Rossi, D. (2015). Mathematics and science teachers' use of and confidence in empirical reasoning: Implications for STEM teacher preparation. School Science and Mathematics, 115(1), 22-34. https://doi.org/10.1111/ssm.12099

Watters, J. J., \& Diezmann, C. M. (2015). Challenges confronting career-changing beginning teachers: A qualitative study of professional scientists becoming science teachers. Journal of Science Teacher Education, 26(2), 163-192. https://doi.org/10.1007/s10972-014-9413-0

Weissglass, J. (1994). Changing mathematics teaching means changing ourselves: Implications for professional development. In D. Aichele and A. Coxford (Eds.), Professional development for teachers of mathematics (pp. 67-78). Reston, VA: NCTM.

Wilkie, K. J. (2019). The challenge of changing teaching: investigating the interplay of external and internal influences during professional learning with secondary mathematics teachers. Journal of Mathematics Teacher Education, 22, 95-124. https://doi.org/10.1007/s10857-017-9376-0

Yackel, E., \& Cobb, P. (1996). Sociomathematical Norms, Argumentation, and Autonomy in Mathematics. Journal for Research in Mathematics Education, 27(4), 458-477. https://doi.org/10.2307/749877

Yackel, E., Rasmussen, C., \& King, K. (2000). Social and sociomathematical norms in an advanced undergraduate mathematics course. Journal of Mathematical Behavior, 19, 275-287. https://doi.org/10.1016/S0732-3123(00)00051-1

Yiğit, N., \& Altun, T. (2011). Effectiveness of an in-service training course: Teaching methods and techniques. Journal of National Education, 41(189), 118-131.

Yllmaz, H., \& Kocasaraç, H. (2010). A new approach to in-service teacher training: The innovative teachers program and its evaluation. Ahi Evran University Education Faculty Journal,11(3), 51-64.

Yin, R. (1984). Case study research: Design and method. Beverly Hills, Sage Publications. 


\section{APPENDIX}

Reformed Teaching Observation Protocol

\begin{tabular}{|c|c|c|c|c|c|c|}
\hline & & $\begin{array}{c}\text { Never } \\
\text { occurred }\end{array}$ & & & & $\begin{array}{c}\text { Very } \\
\text { descriptive }\end{array}$ \\
\hline \multirow{6}{*}{ 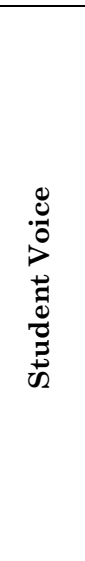 } & $\begin{array}{l}\text {-The instructional strategies and activities respected } \\
\text { students' prior knowledge and the preconceptions inherent } \\
\text { therein. }\end{array}$ & 0 & 1 & 2 & 3 & 4 \\
\hline & $\begin{array}{l}\text {-The focus and direction of the lesson was often determined } \\
\text { by ideas originating with students. }\end{array}$ & 0 & 1 & 2 & 3 & 4 \\
\hline & $\begin{array}{l}\text {-Students were involved in the communication of their ideas } \\
\text { to others using a variety of means and media. }\end{array}$ & 0 & 1 & 2 & 3 & 4 \\
\hline & $\begin{array}{l}\text {-There was a high proportion of student talk and a } \\
\text { significant amount of it occurred between and among } \\
\text { students. }\end{array}$ & 0 & 1 & 2 & 3 & 4 \\
\hline & $\begin{array}{l}\text {-Student questions and comments often determined the } \\
\text { focus and direction of classroom discourse. }\end{array}$ & 0 & 1 & 2 & 3 & 4 \\
\hline & Overall (total/5) & & & $15=$ & & \\
\hline \multirow{3}{*}{ 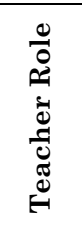 } & $\begin{array}{l}\text {-The teacher acted as a resource person, working to support } \\
\text { and enhance student investigations. }\end{array}$ & 0 & 1 & 2 & 3 & 4 \\
\hline & $\begin{array}{l}\text { - The metaphor "teacher as listener" was very characteristic } \\
\text { of this classroom. }\end{array}$ & 0 & 1 & 2 & 3 & 4 \\
\hline & Overall (total/2) & & & $/ 2=$ & & \\
\hline \multirow{7}{*}{ 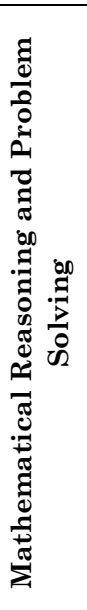 } & $\begin{array}{l}\text { - This lesson encouraged students to seek and value } \\
\text { alternative modes of investigation or of problem solving. }\end{array}$ & 0 & 1 & 2 & 3 & 4 \\
\hline & $\begin{array}{l}\text { - Students were actively engaged in thought-provoking } \\
\text { activity that often involved the critical assessment of } \\
\text { procedures. }\end{array}$ & 0 & 1 & 2 & 3 & 4 \\
\hline & - Students were reflective about their learning. & 0 & 1 & 2 & 3 & 4 \\
\hline & $\begin{array}{l}\text { - Intellectual rigor, constructive criticism, and the } \\
\text { challenging of ideas were valued. }\end{array}$ & 0 & 1 & 2 & 3 & 4 \\
\hline & $\begin{array}{l}\text { - Active participation of students was encouraged and } \\
\text { valued. }\end{array}$ & 0 & 1 & 2 & 3 & 4 \\
\hline & $\begin{array}{l}\text { - Students were encouraged to generate conjectures, } \\
\text { alternative solution strategies, and/or different ways of } \\
\text { interpreting evidence. }\end{array}$ & 0 & 1 & 2 & 3 & 4 \\
\hline & Overall (total/6) & & & $16=$ & & \\
\hline \multirow{5}{*}{ 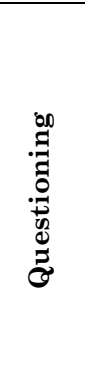 } & $\begin{array}{l}\text { - The teacher's questions triggered divergent modes of } \\
\text { thinking }\end{array}$ & 0 & 1 & 2 & 3 & 4 \\
\hline & $\begin{array}{l}\text { - The teacher's questions targeted students previous } \\
\text { knowledge }\end{array}$ & 0 & 1 & 2 & 3 & 4 \\
\hline & $\begin{array}{l}\text { - The teacher used the questions effectively to start and } \\
\text { follow up negotiation process }\end{array}$ & 0 & 1 & 2 & 3 & 4 \\
\hline & $\begin{array}{l}\text { - The teacher asked follow up questions to pursue students' } \\
\text { reasoning }\end{array}$ & 0 & 1 & 2 & 3 & 4 \\
\hline & Overall (total/4) & & & $14=$ & & \\
\hline
\end{tabular}

